\title{
REFLECTIONS ON CONSUMER LAW AND POLICY IN SEYCHELLES
}

\author{
Marco Rizzi* \\ Introduction
}

The Republic of Seychelles is a small island state, population 97,000 as of January 2017, ${ }^{1}$ situated in the Western Indian Ocean. Despite its reduced dimensions it faces the challenges of a young fully sovereign nation. All the inherent difficulties stemming from post-colonialism are accentuated by its peculiar colonial history that has seen, in succession, French and British domination. ${ }^{2}$ The legal system resulting from this dual influence is a "mixed jurisdiction" (Twomey 2017) involving very interesting entanglements. In a nutshell, public and criminal law are essentially based on UK common law (though with notable peculiarities, such as the presence of a Seychelles Penal Code that crystalizes English criminal law at the date of its approval in 1955), whereas private law matters are disciplined by the Seychelles Civil Code, a direct English translation of the French Code Civile, that raises important issues of interpretation and can only benefit from the guidance of French case law insofar as the latter does not involve reference to any legislation posterior to 1973 (the year the Civil Code was approved in Seychelles). Legal scholarship is still at an embryonic stage in the country, while local legal education is mostly focused on English law, ${ }^{3}$ and Seychelles law is only studied in concentrated fashion in preparation for the local Bar Exam. As a result, the Seychellois "legal voice" is still very much a work in progress and there is a shortage of secondary sources to alleviate difficult interpretative tasks for judiciary, legal practitioners and law reformers alike. ${ }^{4}$

While the influence of the French legal tradition is undeniable, the dynamics of the legal system as a whole are more akin to the common law. Numerous examples attest this tendency. In legal practice, we can observe difficulties of Seychelles courts and attorneys at law when confronted with issues of droit de superficie in property law (Wong 2017), or the odd use of English precedents on 'duty of care' and 'breach of duty' to interpret the French concept of faute in cases of responsabilité délictuelle (particularly in cases involving liability of skilled professionals, such as medical practitioners). ${ }^{5}$ The prevalent

${ }^{*}$ Senior Lecturer, University of Western Australia, UWA Law School.

${ }^{1}$ Data estimates on population produced by the United Nations portal UNDATA - A World of Information, available at http://data.un.org/CountryProfile.aspx?crName=SEYCHELLES\#Top (last accessed 15 April 2018).

2 Seychelles was initially settled by the French in 1770, and the first laws enacted in 1788 . By 1810 the region (including the larger island of Mauritius) capitulated to the British who had fought vigorously over the Western Indian Ocean islands for the control of the route between India and the Cape. Independence was gained on 29 June 1976 (Twomey 2013).

3 The University of Seychelles has been offering the University of London International Programme LLB since 2010.

4 The latest and most comprehensive work on Seychelles law is the published version of the PhD thesis of the Chief Justice of the Seychelles Supreme Court Dr. Mathilda Twomey, Legal Métissage in a Micro-Jurisdiction: the Mixing of Common Law and Civil Law in Seychelles (2017), Journal de Droit Comparé di Pacific, Collection 'Ex Professo' Volume VI. Another valuable source is Jessica Kerr, 'Finding the Law in Seychelles' (2015) GlobaLex, available at http://www.nyulawglobal.org/globalex/Seychelles.html (last accessed 15 April 2018).

${ }^{5}$ In the recent decision François Octobre vs The Government of Seychelles [2016] SCSC 941 the Supreme Court of Seychelles stated that the consistent use of English negligence cases, such as 
influence of the common law is even more recognizable in legislative drafting. An example from consumer law is product liability. Instead of being incorporated in the Civil Code as was the case in France, special provisions are laid out in section 45 of the Consumer Protection Act of 2010 - which is particularly significant insofar as jurisdiction over violations of the Act is vested, at first instance, in a quasi-judicial body, not in the courts.

The position of consumers is an interesting one in Seychelles: while the small dimensions of the country allow for relatively easy direct interactions between consumers and sellers, and while relevant statutory authorities are accessible and proactive, structural challenges make it difficult at times to provide effective protection. These challenges include lack of standardization, lack of interpretative guidance from courts and quasi-judicial bodies, limited capacity and resources, unclear legal provisions, and the overarching issue of being a micro-market with no local consumer product manufacturers and limited capacity to reach out to foreign manufacturers where remedies are needed.

The article commences with an overview of the origins and general characteristics of consumer law in the first part; it discusses consumer law in context in the second part (through an analysis of general statistics and subjectdefined case studies); and ends with a brief discussion on the interactions between Seychelles consumer law and other international or supranational initiatives.

\section{Origins and General Characteristics of Seychelles Consumer Legislation}

\section{Social, Political and Economic Background}

Consumer law in Seychelles has developed as an autonomous legal field over the past 20 years, since the adoption of the first Consumer Protection Act, No 4 of 1997. 6 This original piece of legislation has been deemed unsatisfactory by courts, and practically never relied upon by aggrieved consumers, due to a lack of adequate and justiciable remedies, as well as significant gaps in the legislative provisions (e.g. the absence of any special provision on product liability as discussed by Twomey (2017, pp. 106-107)). The Consumer Protection Act, No 30 of 2010 (CPA), which repealed its predecessor, was drafted and approved at a time when the socio-economic landscape of the country was evolving at great speed. The task of overseeing the final draft of the CPA was bestowed upon a current judicial officer, who at the time was serving as a State Counsel in the Attorney General's Office. ${ }^{7}$ When asked about her experience in carrying out this task, the officer reported a fundamental lack of policy guidance from the political sphere. This is a symptom of the difficulties the country is facing in developing a fully fleshed consumer protection culture, which will be analysed below.

Bolam v Friern Hospital Management Committee (1957)1 WLR 582, by Seychelles courts to found medical liability is "an aberration and must be disregarded".

${ }^{6}$ All Seychelles legislation and case law referred to in this article can be accessed through the Seychelles Legal Information Institute (SeyLII) at www.seylii.org.

7 The AG's office in Seychelles bears a number of different responsibilities, including in particular prosecution and legislative drafting. Due to limited capacity and very limited human resources, it is not uncommon for State Counsels to take on drafting duties. 
However, before discussing the structure and characteristics of Seychelles consumer law, it is necessary to consider elements of the country's political and economic recent history. Seychelles is part of a group of Small Island Developing States (SIDS) that has been defined by the United Nations (UN) as a "distinct group of developing countries facing specific social, economic and environmental vulnerabilities" (UN - OHRLLS). Essential characteristics of SIDS have been extensively discussed by UN agencies such as UNCTAD, UNESCO, UNEP and the UN Conference on Sustainable Development. These include (Briguglio 1995, 16151632):

- Small domestic markets lacking economies of scale with a tendency to be dominated by oligopolies and monopolies, with small numbers of companies prone to cartel behaviour;

- Heavy dependence on imports and external markets;

- Remoteness of location with long distances from export markets - which impacts prices and diversification of available products, and exposes SIDS to the risk of dumping by multinational companies;

- Limited economic diversification - Seychelles in particular is heavily dependent on tourism and fisheries;

- Reliance on public sector and significant participation of the public sector in the economy;

- Limited availability of skilled labour, which can impact prices of final products for consumers;

- Lack of primary industry due to limited availability of primary resources;

- Growing population;

- Dependence on a narrow range of products and services;

- Elevated costs of energy, transports and communication services which impacts prices of products and services.

In addition to these general features we must consider that Seychelles experienced a long history of planned economy, starting in 1977, the year Albert René, leader of the Seychelles People's Progressive Front (SPPF, subsequently renamed Parti Lepep), led a coup d'état resulting in the overthrow of the first postindependence democratic government, elected in 1976. The ensuing one-party regime, part of the socialist block, lasted until 1993 when the country approved its new constitution and the exiled founding president, Sir James Mancham, was allowed back into the country. While Seychelles has been formally a multi-party democracy since then, it was only in September 2016 that a coalition of opposition parties under the acronym of LDS (Linyon Democratic Seselwa) managed to win the majority in the National Assembly, resulting in a complex cohabitation between the LDS-controlled legislative power and the executive in the hands of Parti Lepep.

Since the late seventies and for over thirty years, the model of economic development, reminiscent of other socialist states, was built around the adoption of five-year plans. The social and economic development of Seychelles has been relatively successful thanks to these policies, especially when compared to other African countries (WB 2016), but it proved unsustainable in the long term.

In 2008, after thirty years of growing external debt, the public debt to GDP ratio reached $150 \%$ with a contraction of economic growth to $1,3 \%$ (IMF 2017). Inevitably, the country had to rely on foreign aid, specifically International Monetary Fund (IMF), World Bank (WB) and the African Development Bank 
(ADB). International aid came with substantial strings attached: significant reforms had to implement privatization and liberalization policies in order to replace price controls with market-driven mechanisms, liberalize imports and trade to foster competition, and cut expenditures to reduce budget deficits. Abrupt trade liberalization, which culminated in Seychelles' accession to the World Trade Organization (WTO) in $2015,{ }^{8}$ was the trigger for a sudden rise in consumerism as the country gained access to large amounts of diverse types of products that were impossible to find on the islands before.

In 2015, seven years after the first wave of reforms, the World Bank certified their success, acknowledging that the GDP per capita had reached USD 15,476 per annum and reclassifying Seychelles as a high-income country (WB 2017). While these macro indicators paint a favourable picture, they fail to reflect the reality that the minimum wage is roughly USD 440 per month, which is inadequate to the islands' elevated cost of living. The African Development Bank points out a number of critical obstacles to the growth of a competitive private sector in Seychelles including limited access to credit, unclear business regulation and lack of internal competition (ADB 2016). Moreover, structural problems are still affecting the country's prospects such as skill mismatches that are problematic for high-quality job-performance and creation (WB 2017).

The 2008 reforms, alongside liberalization, included a series of other policy, legislative and institutional reforms impacting the internal market. A key Act was the Fair Trading Commission Act, No 17 of 2009 (FTCA), which established the Fair Trading Commission (FTC), a new public agency tasked with the administration of two significant pieces of legislation: the Fair Competition Act, No 18 of 2009 (FCA) and the CPA. The most relevant governmental policy in place at the time to provide guidance in the legislative drafting was the "Seychelles 2017 Strategy", a document laying down general goals including improvement of macro-economic management and the enhancement of competitiveness and governance. A dedicated National Competition Policy for Seychelles was finally adopted in 2014, and provides guidance to the FTC in the implementation of the FCA (FTC 2014). Consumer policy did not receive the same level of attention.

The fate of the National Consumer Policy (NCP) is a good example of the difficulties of SIDS in achieving policy and regulatory reform. No consumer policy was developed before May 2016, when the NCP was submitted by the FTC to the attention of Cabinet. The NCP is the product of a consultancy provided to the FTC by the Common Market of East and Southern Africa (COMESA) Competition Commission. The document is supposed to, inter alia, offer policy guidance to the FTC, which is currently in the process of putting together a structural reform of the CPA - a project that aims to consolidate the two main consumer related acts (FTCA and CPA, as discussed below) into one single piece of legislation by the end of 2018.

To facilitate the preliminary steps of this reformatory task the FTC resorted to the services of another consultant, this time affiliated with the Southern African Development Community (SADC). Interestingly, in a report dated August 2016 (three months after the submission of the NCP to Cabinet), the consultant states the following: "Seychelles does not have an explicit Consumer Protection Policy. To arrive at some policy principles the Consultants considered the requirements

8 Details of Seychelles' Accession Procedure to WTO are available at https://www.wto.org/english/thewto e/acc e/a1 seychelles e.htm (last accessed 15 April 2018). 
of the UN Guidelines for Consumer Protection" (ConsumerWeb 2016, 26). Despite having been submitted to Cabinet in May 2016, as of October 2017 the NCP is yet to be officially adopted and implemented.

Various reasons contribute to explain this long delay. In particular, at the time when the NCP was submitted to Cabinet, the Seychelles Constitutional Court was on the verge of delivering its judgment on an extremely sensitive challenge to the presidential election held in December 2015. 9 The decision to uphold the contested result (finding in favour of the incumbent) was received with extreme hostility by the opposition. That discontent fuelled the campaign for the legislative election, held in September 2016. The result saw LDS, the opposition coalition, winning a comprehensive majority in the Assembly, which ultimately led to the resignation of President James Michel in favour of his Vice-President Danny Faure (The Nation, 2016). With the new President came a new Cabinet, which is working in difficult cohabitation with the majority in the Assembly. Within the current unsettled political scenario consumer policy struggles to be a priority.

\section{Characteristics of Seychelles Consumer Legislation}

\section{The Fair Trading Commission}

The key actor in Seychelles consumer law is the FTC, an administrative agency created under the FTCA 2009. The FTCA establishes the FTC (section 3) as a body corporate, a somewhat obscure concept signifying a degree of independence from the government but with direct involvement of the President of the Republic and of the Minister for Trade (section 2) in key aspects of the FTC's life. For instance, the Board of the FTC is appointed by the President of the Republic. A number of entities share this rather ambiguous status in Seychelles. In order to provide a clear legal framework for such entities and to avoid the risk of undue political influence, a Bill was passed by the National Assembly in 1989, the Parastatal Corporations Act, No 2 of 1989. However, the commencement of the Act was left for future announcement in regulations, and as a result this Act (despite having received Presidential assent) has never been brought into force, leaving a vast grey area regarding governmental control over a number of public entities ranging from agencies such as the FTC to higher education organizations such as, for example, the Seychelles Tourism Academy and the University of Seychelles.

\footnotetext{
${ }^{9}$ In the second round of the 2015 presidential election, the incumbent James Michel (of Parti Lepep) faced Wavel Ramkalawan (candidate of the LDS coalition) and managed to beat him by the smallest of margins (less than two hundred votes). LDS contested the results on two grounds. First, an interpretation of the constitution and of the electoral law - specifically on the meaning of the words "votes cast" - with the intent to show that Mr Michel had not in fact received the majority of votes cast but only of valid votes. The court dismissed the petition on the grounds that votes cast and valid votes have to be interpreted as equivalent expressions. Secondly, LDS claimed there were irregularities in the electoral process (bullying of voters by Parti Lepep activists, multiple voting by same voters, buying of identity cards by Parti Lepep). The court, while satisfied that some irregularities indeed took place, found in favor of the incumbent and upheld the election's result on the grounds that the petitioner had failed to meet the burden of proof - there was insufficient evidence that the irregularities had an impact on the final result, and insufficient evidence to trace those irregularities back to the incumbent himself. See Ramkalawan v Electoral Commission and Ors (Valid votes) (CP 07/2015) [2016] SCCC 10 (31 May 2016), and Ramkalawan v Electoral Commission and Ors (Election noncompliance and illegal practices) (CP 01/2016) [2016] SCCC 11 (31 May 2016), available at https://www.seylii.org/courtnames/constitutional-court/2016 (last accessed 15 April 2018).
} 
The FTC has a number of powers including investigation, management of consumer complaints and quasi-judicial functions. The exact functions and investigative powers of the FTC in the field of consumer law are disciplined by the CPA, so that the most relevant part of the FTCA for consumer matters is Part VI, which disciplines the "Hearings before the Commission". The FTC has "exclusive jurisdiction" (section 38) to hear and determine any matter related to the protection of consumers and fair competition. Hearings are held before the Board where the complainant can be heard either in person or represented.

Upon the Board's decision, the FTC issues an "order", which has to be served to the company against which it is issued and published with motivations within a month (sections 42 and 43). ${ }^{10}$ The Board's decisions can be challenged in the Appeal Tribunal, which is regulated in detail by Schedule 2 to the FTCA. It is appointed by the Minister responsible for Trade and, unlike the first instance Board, it is a tribunal of record. Its competence is general and includes the power to confirm, quash or vary the determinations of the Board in the forms of "orders" or "directions". Finally, orders and directions issued by the Tribunal can be appealed before the Supreme Court.

\section{The Consumer Protection Act}

The principal piece of legislation governing consumer protection and consumer rights is the CPA. Parts II and IX focus on the powers and functions of the FTC in the enforcement of the Act, whereas Parts III to VII lay down the substantial consumer protection provisions.

Part II ("Fair Trading Commission") is essentially a revised version of significant portions of the FTCA. It lays down the powers and functions of the FTC in the application of the CPA. The ensuing duplication of norms with FTCA is a source of confusion and one of the drivers behind the current reformatory process. The overarching goal of the FTC under the CPA is "the achievement and maintenance of a consumer market that is fair, accessible, efficient, sustainable and responsible for the benefit of consumers generally" (section 3(a)). Its functions can be summarized as follows: the FTC can a) receive or initiate complaints of CPA violations; b) investigate and evaluate complaints; c) issue and enforce compliance notices; d) conduct hearings in accordance with the CPA and the procedure laid down in the FTCA; e) impose remedies, fees and fines; f) monitor the consumer market to prevent illegal conducts; g) promote consumer awareness.

Whenever a complaint is received or initiated, the FTC can exercise a range of investigative powers including the ability to enter and search premises, inspect, and remove documents relevant to the investigation. When the FTC is satisfied that there is enough substance to a complaint it initiates hearings (conducted under the FTCA). The FTC is also the entity responsible for the enforcement of the CPA, which entails the power to issue compliances notices and interim orders.

The bulk of the CPA consists of provisions on the substance of consumer protection. The part dedicated to unfair contract terms is reminiscent of the 1993 homonymous European Directive. While the norms on "terms not individually negotiated" is almost a verbatim transposition of Article 3(2) of the Directive, section 14 on "unfair terms" make no reference to the concept of "good faith",

${ }^{10} \mathrm{~A}$ repository of the Board's decisions is available at http://ftc.sc/index.php/board-ofcommissioners (last accessed 15 April 2018). 
which plays a key role in the European context. This is an interesting choice considering that even the UK included the formulation in their national implementation of the Directive despite not being privy to the concept, whereas the Seychelles jurisdiction knows good faith from its Civil Code's provisions on the law of obligations. The effects of unfairness are again inspired by the EU legislation, as the unfair term is "not enforceable against a consumer" (section 16).

As regards unfair trade practices, the drafters of the CPA took as their main source of inspiration the South African legislation (with the difference that the Seychelles CPA condenses into one coherent part a number of provisions on unfair practices that are not disciplined together in South African law). Unlike the part on unfair contract terms, in this area the influence of EU directives (such as the B2C directives) is less prominent, and the level of detail of individual provisions is not as pronounced.

The provisions on consumer product safety and quality will be touched upon in the next part of the article, dedicated to consumer law in action.

\section{The Seychelles Bureau of Standards Act}

Several statutes are relevant to consumer law despite being outside the scope of "FTC laws" (i.e. laws the FTC is legally mandated to administer). ${ }^{11}$ Of particular importance for consumer protection is the Seychelles Bureau of Standards Act, No 2 of 2014 (SBSA). The Seychelles Bureau of Standards (SBS) ${ }^{12}$ established under the Act (yet another "body corporate") is responsible for a variety of tasks including (i) development and implementation of Seychelles standards; (ii) laying down provision for use of standard marks; (iii) making arrangements or providing facilities for the examination and testing of commodities and any material or substance used in their production and processing; (iv) providing for the testing of commodities manufactured in Seychelles or imported into the country to ascertain their compliance with relevant standards (the functions are listed in detail in section 4 ).

As is the case for other similar institutions in the Commonwealth (for example the Indian Bureau of Standards (Rizzi 2017)) the SBS only adopts voluntary standards. Under section 17, the Minister responsible for Industry can declare a Seychelles Standard mandatory when the SBS recommends it on the basis that a commodity (a generic term indicating "an article, product or thing which is the subject of trade and commerce") may affect public safety, health or the environment. To date, only five standards have been declared mandatory. ${ }^{13}$

\section{The National Consumer Policy}

Because it is only recently that the country has started experiencing consumerism, the scholarly distinction between first- and second-generation consumer law has

\footnotetext{
11 Other than the SBSA these include: the Broadcasting and Telecommunications Act, No 2 of 2000; the Energy Act, No 11 of 2012; and the Financial Services Authority Act, No 19 of 2013.

12 More information on the Bureau is available at http://www.sbs.sc (last accessed 15 April 2018).

13 The five mandatory standards are: (i) SS9:1991 - Rev.3:2005 (S.I.38:2005) - Specification for Concrete Blocks; (ii) SS11:1991 Rev.2:2005 (AMD.1:2006) - Specification for Periodic Inspection and testing of refillable gas cylinders; (iii) SS23:1994 - Rev.1:2004 (S.I.20 of 2004) Specification for Toilet Soap; (iv) SS33:19994 - Rev.1:1999 (S.I.34 of 1999) - Specification for modified UHT and modified pasteurized skimmed, partly skimmed and full cream milk; (v) SS54:1999 (S.I. 53 of 1999) - Specification for Seychelles Time.
} 
little practical meaning in this context. As we have seen the FTC is an independent body with regulatory, investigative and quasi-judicial functions, while the SBS is tasked with standard setting - two typically second-generation features. Both of them predate the adoption of the CPA 2010, which in turn contains elements of both first and second-generation (e.g. unfair contract terms and product liability on one hand, provisions on delivery of services on the other). It is consumer law in general that is still in its youth in Seychelles.

As mentioned above, to supplement black letter law the FTC has collaborated with a COMESA consultant to develop a National Consumer Policy. The NCP would move from the CPA objectives to add three complementary policy goals: (i) the protection of consumers from hazards to their health, safety and environment; (ii) the enhancement of consumer policy effectiveness through education, information and advocacy programmes; (iii) mainstreaming of consumer policy within government policy-making and development strategies (such as partnerships among institutions and stakeholders in the field) (FTC 2016a, 16).

There is a clear influence of the UN Guidelines for Consumer Protection (UNGCP) (UN 2016) for example as regards the necessity to ensure consumer protection enforcement authorities are given sufficient human and financial resources (which falls within the scope of "mainstreaming", NCP 2016, 18), or the focus on consumer information programmes. In particular as regards the latter, the NCP includes a commitment to develop programmes taking into account local priorities, focusing on accessibility (linguistic and material) (FTC 2016a, 19). Moreover, several broad-reaching educational campaigns are being developed by FTC taking inspiration from foreign experiences. The most relevant are the following: (i) leaflets informing consumers of their rights on shopping sites (inspired from the initiative of the Competition and Consumer Protection Commission of Ireland); ${ }^{14}$ (ii) the development of a Consumer Charter inclusive of all consumer rights and responsibilities (modelled after the initiative of the Fair Trading Commission of Barbados); ${ }^{15}$ (iii) simple explanations of consumer protection laws (taken from the Fair Trading Commission of Jamaica); ${ }^{16}$ (iv) general information leaflets (as developed by the Competition and Consumer Affairs Authority of Malta). ${ }^{17}$

Because of the limited resources available for consumer protection, the NCP includes a mechanism to establish different levels of priority of consumer complaints. In line with UNGCP, the first criterion is the protection of consumer health and safety. Secondly the FTC should take into account whether the practice complained against adversely affects "vulnerable and disadvantaged consumers". The source of inspiration here is the definition adopted in Australia by the Consumer Affairs body of the state of Victoria (CAV) (CAV 2004). Finally, the NCP indicates as a prioritization criterion the "extent of detriment, seriousness of conduct and public interest" (a multifaceted concept borrowed from the New

\footnotetext{
${ }^{14}$ An overview is available at https://www.ccpc.ie/consumers/shopping/ (last accessed 15 April 2018).

15 The Charter, developed in 2010, is available at http://www.ftc.gov.bb/index.php?option=com_content\&task=view\&id=178 (last accessed 15 April 2018).

16 The list of individual explanations is available at http://jftc.gov.jm/tips-advice/for-consumers/ (last accessed 15 April 2018).

17 The Consumer Information Leaflets are available at http://www.mccaa.org.mt/en/publications (last accessed 15 April 2018).
} 
Zealand Commerce Commission). ${ }^{18}$ In parallel to prioritization, the NCP develops mechanisms for market analysis with the intent to promote prevention and the identification of suitable and effective reactions. These mechanisms are based on the six-step sequential process recommended by the OECD Consumer Policy Toolkit (OECD 2010).

As already discussed above, the Seychellois political scene is rather unsettled at the moment and, despite the FTC's efforts, consumer law and policy has momentarily taken a back seat. Therefore, the NCP is currently a simple internal FTC document and as such, while it inspires the actions of the FTC, it cannot commit government to further resources, nor does it have any effect on other agencies, such as the SBS - which is problematic insofar as interagency cooperation is paramount to the success of the NCP goals.

\section{Selected Features of Consumer Law in Action}

The sources used for this part are, on one hand, public documents such as FTC annual reports and decisions of the Board of Commissioners and Appellate Tribunal (all available on FTC's website: www.ftc.sc), and on the other hand a series of interviews held with legal and compliance officers of the FTC's Legal Affairs and Policy department and Consumer Affairs department. The first section discusses general statistics on FTC's marketing surveillance activities. The following section shifts the focus to specific areas of consumer protection in order to provide a sense of how CPA and SBS provisions operate in everyday practice, in a context with limited human, financial and interpretative resources.

Recent Statistics on Market Surveillance and Consumer Complaints in Seychelles

The FTC conducts regular marketing surveillance activities, in line with UNGCP and the internal NCP. In the year 2016 FTC carried out a total of 116 inspections of businesses and outlets (that is 61\% more than the previous year, 2015, when 72 inspections took place) (FTC 2016b, 16). A total of 66 inspected businesses were found in contravention of CPA provisions on unfair trade practices (that is, $65 \%$ of the total). The largest number of breaches of the CPA involved section 20 (failure to disclose price of goods for sale) and section 19 (failure to inform in plain and understandable language). Other statistically significant breaches emerging from routine inspections involved violations of section 24 (offering goods for sale past their expiry date), section 32(i) (false representations on warranty), and section 22 (false labelling or inadequate description). In analysing these numbers and the major challenges it faced over the period under review, the FTC reports a substantial "lack of cooperation from stakeholders" (FTC 2016b, 19), which is identified as the primary issue behind the high percentages of violations. As aptly put by FTC's Legal Advisor, "challenges to consumer protection in Seychelles are often an issue of insufficient education on both sides, businesses and consumers".

The picture regarding consumer complaints is as follows. In 2016, FTC registered a total of 342 complaints (a 10\% increase from 2015 when 311 complaints were lodged) (FTC 2016b, 22). The breakdown of these complaints

\footnotetext{
18 The enforcement criteria of the New Zealand Commerce Commission are available at http://www.comcom.govt.nz/the-commission/commission-policies/enforcement-criteria/ (last accessed 15 April 2018).
} 
sees 203 cases lodged on consumer goods, and 139 on services (82 of which regard construction services). While complaints on services are stable, consumer goods have seen a significant 21\% rise in just one year (from 175 in 2015). Out of the 342 complaints submitted to FTC in 2016, 180 were discontinued within the year (whereas 162 were carried over to 2017, with statistics on these cases not yet available). While 79 were dismissed for lack of merit, 100 received redress (prevalently in the form of refunds, repairs or replacement of defective goods, either separately sold or supplied in the course of a service) and one was referred to the Board to be adjudicated.

Electronic devices are the most targeted with 157 complaints out of the total. FTC identifies as the key factor behind the steady increase the "importation of poor quality products" and the fact that "there are no mandatory regulations for the standards of goods entering the market" leading to an "increase in substandard products entering the country" (FTC 2016b, 23).

Pharmaceutical products are another category of goods experiencing a progressive increase in complaints. This is a very delicate sector as a number of new private pharmacies are opening and availability of medicines is proportionally on the rise. A sector-specific Medicines Act is yet to be adopted, ${ }^{19}$ and there are no clear rules on minimum standards of safety and efficacy for the import of pharmaceutical products by private businesses. Because of the difficulties FTC is facing in dealing with this highly technical field, the NCP lays down a series of guidelines for a Memorandum of Understanding between FTC and the Public Health Authority (PHA) to receive technical support from PHA when evaluating medicines.

\section{Examples of Consumer Law in Action}

\section{Product Safety \& Product Liability}

Product safety is an intricate issue in Seychelles. The relevant legislative provisions can be found in the CPA, particularly sections 49 and 50 . These two sections lay down a strong general safety requirement. For example, section 49 states that "'safe' in relation to any goods, means that there is no risk, or no risk apart from one reduced to a minimum". Section 50 establishes that goods fail to comply with the general safety requirement "if they are not reasonably safe having regard to all the circumstances" - including the manner in which the goods are marketed, the use for which they are marketed, their structure and composition, the presence of standards.

The main issue that FTC officers face in the application of this safety requirement is the fact that there are virtually no standards to provide adequate benchmarks. Section 50(2)(b) mentions mandatory and officially published voluntary standards adopted by SBS among the circumstances to take into account. However, as there are only five mandatory standards, the vast majority of complaints fall outside their scope, and voluntary standards have little impact. ${ }^{20}$

\footnotetext{
${ }^{19}$ A Medicines Bill, modeled after its South African equivalent, was submitted to the Attorney General's Office in May 2015, but it is yet to be presented to Cabinet for approval.

20 The topic was discussed in various interviews, including one with an FTC Market Analyst who is in the process of finalizing a study suggesting that the reasons for the low success of voluntary standards are the reduced dimensions of the market and the ensuing relatively small
} 
This lack of standardization is particularly penalising for a small country highly dependent on imports. As a matter of fact, Seychelles ports of entry encounter great difficulties in differentiating safe from sub-standard products. ${ }^{21}$ One of the points introduced by the NCP is a rolling monitoring of international databases on product safety or defective products (such as those kept by the Australian Competition \& Consumer Protection Commission, the EU Commission, the United States or the OECD) in order to alert customs authorities to prevent these products from entering the country (FTC 2016a, 28). Lack of human and financial resources make it however difficult for the FTC to effectively implement this measure.

A separate issue is labelling: sections 19 (on plain and understandable language) and 22 (on the indication of prices) impose general labelling requirements but without detailed specifications, which should be issued in separate regulations. These should be promulgated as statutory instruments by the competent ministry, but structural delays hinder the effectiveness of the provision. For example, the FTC is still awaiting regulatory provisions on the indication of expiration dates on consumer goods.

The lack of standardization leaves a certain margin of manoeuvre to the FTC to make its own assessments on product safety. In particular, FTC can issue prohibition notices for the stop of sales under section 52 and, in more extreme cases, order a compulsory recall of goods (section 54). This has only been done on six occasions in cases involving defective electronic appliances and defective construction materials. ${ }^{22}$ The most common option is the prohibition notice, which is normally accompanied by a recommendation for a voluntary recall. ${ }^{23}$

Before the adoption of the CPA, liability for defective goods fell within the scope of general tort law, and in particular Article 1383(1) of the Civil Code. There are three interesting leading cases, factually similar to the English cornerstone decision Donoghue $v$ Stevenson. These are Camille (glass in a beer bottle), ${ }^{24}$ GrandJean (lizard in cola bottle), ${ }^{25}$ and Aithal (lizard in a bottle of ginger ale). ${ }^{26}$ The first case was decided on the basis of the common law principle of "the good neighbour" set in Donoghue. The Aithal case realigned Seychellois jurisprudence as the Supreme Court established that the burden of proof of the efficiency of a manufacturing process should shift to the defendant when it is peculiarly within their knowledge (Twomey 2017, 106).

Since 2010 the matter is governed by section 45 of the CPA, which establishes a similar (although somewhat convoluted in wording and structure) regime to Western product liability models: a strict liability regime with exceptions. The FTC being the competent agency to administer the entirety of the CPA, jurisdiction for product liability falls on the Board at first instance (the Supreme Court coming into play only as a second and final appeal). Section 45(3) identifies to whom the provision applies: (i) the producer; (ii) whomever puts

competition. There is no incentive to adopt standards and endure the cost of meeting them if this is to have little or no impact on sales.

${ }^{21}$ Interviews with FTC Compliance Officer and Customs Officers.

${ }^{22}$ FTC compulsory recall notices are available at http://ftc.sc/index.php/consumer-protection (last accessed 15 April 2018).

23 This has been recently the case when a brand of milk based drinks received a prohibition of sales notice and a strong warning to the population, resulting in the retailer voluntarily recalling all products.

${ }^{24}$ Camille v Seychelles Breweries Ltd SC 6/1996 (unreported).

25 GrandJean v The Seychelles Breweries Co Ltd SC 368/1996 (unreported).

${ }^{26}$ Aithal v Seychelles Breweries Ltd SC 52/2004 (unreported). 
their name or distinguishing trade mark on the product to hold themselves as the producer; (iii) the importer. Since 2010 there have been no product liability cases initiated by the FTC. Considering that there is no lack of defective products on the market, FTC Legal Affairs and Consumer Affairs officers suggest that there are two main reasons for this. First, aggrieved consumers prefer other remedies, such as repairs, refunds, replacements - given the wording of section 45(6) on "Damages", theoretically a consumer could sue even for material damages only to the product itself. Secondly, in the few cases where a complaint was raised it was also quickly withdrawn and settled outside of the FTC redress system.

\section{Consumer Products}

Going further in the analysis of consumer products governance in practice, it is important to underline that any matter is brought by a complainant against the retailer or the seller and never the manufacturer as consumer goods are always imported. Warranties, pursuant to section 42 CPA, are typically sought from the retailer (though section 42 makes only a generic reference to the "supplier") and always cover a period of six months, which is the minimum provided for under the Act, but no regulation imposes a different time on specific products, nor do companies have any incentive to offer more. The only category of goods for which the normal warranty is longer is cars (two years or up to $100,000 \mathrm{~km}$ ). Warranties under the CPA are always "in addition to" other warranties stipulated contractually, or other mandatory legally compulsory warranties such as the basic warranties under the general law of obligations (including the warranties against eviction and defects of the property).

In practice, both Legal and Consumer Affairs officers note that the prevalent behaviour among retailers and sellers is to provide a generic warranty without specifications (the relevant document being the receipt which does not contain any indication), and in the face of a complaint to attempt to define its scope $e x$ post. For example, in the sale of computers or mobile phones, a number of complaints are based on the grounds that sellers maintained the warranty "does not cover batteries". Here the legal route can be twofold. FTC normally construes section 42 CPA as including subsidiary goods (such as batteries) in the general "fitness for purpose" test. However, as this construction is not always an obvious one, FTC officers can resort to unfair contract terms provisions. The issue there is that Schedule 1 of the CPA does not mention warranties explicitly, so that FTC has to rely either on general provisions (e.g. terms not individually negotiated under section 11), or Article 1a of the Schedule (on exclusion of liability in respect of quality, which can be interpreted as including partial guarantees).

A peculiar issue is the one involving delivery and transit. As Seychelles is a small market, typically goods are bought directly in the shop, and there is normally no delivery service so that transit is the responsibility of the consumer. When the goods are not in the country, the consumer can order them online or the shop does it on behalf of the consumer - in both cases there is no remedy against delays as these are either due to international transport or to the customs authorities keeping the goods for inspections at the port of entry. What does happen frequently however is a delay in the supply of goods within the delivery of a service. A typical example is the delay in the supply of construction materials in construction contracts. This falls within the scope of section 40(1) that lays down the standards of performance of services. As reported by FTC's Legal Advisor, 
these cases are commonly decided by the Board through an informal mediation process (i.e. not the formal adjudicatory process laid down in the FTCA discussed above), and in that context the Board accepts as a defence "reasonable explanations for the delay". This is a rather broad construction of the narrow exceptions provided by section 40(3), that only cover cases in which the failure of the supplier is due either "(a) to the act or default of another person; or (b) an accident or cause beyond the control of the supplier."

\section{Telecommunications}

This is an area of particular interest in modern consumer law and policy. For instance, it is common to every major Western country that mobile phones can be sold in connection with one- to two-year service contracts with telecom companies. This raises a series of issues such as, for example, the ability of a consumer to cancel one contract and move to a different service provider, switch from one provider to another while maintaining the same phone number, and use a smartphone as a "catch all device". In these circumstances telecom providers can be required to offer adequate protection to their clients.

FTC's Consumer Affairs notes that generally speaking, these issues are not particularly relevant to Seychelles consumer law at the moment. Contracts tying the purchase of a phone to a certain period of service with a telecom provider only exist at corporate level in business to business transactions. Consumers do not buy phones with contracts attached. Instead, they tend to buy phones as their own items in electronic shops. As regards smartphones, a common scenario sees consumers buying them overseas (especially in the United Arab Emirates or in South Africa where electronic goods are significantly more affordable than in local shops). For this reason, there cannot be any overlap between the liability of the retailer of the phone and that of the telecom service provider in case of product defectiveness - the liability remains with the retailer. Theoretically, if a good is bought under the umbrella of a service, the CPA would offer a special protection under section $40(1)(\mathrm{c})$ according to which "[the supplier shall] where goods are required for the performance of the service, use, deliver or install goods that are free of defects and are of a quality that persons are generally entitled to expect". However this possibility is not material to the current reality of Seychellois telecommunications consumerism.

The vast majority of consumers use prepaid sim cards and top-up services both for network and for mobile data. Between 2013 and 2014 FTC has seen a significant surge in complaints against mobile service providers for various types of qualitative inadequacies essentially focusing on alleged unfairness of price per minute (FTC 2013 and FTC 2015). In their report on the effectiveness of Seychelles consumer complaint management mechanisms, SADAC consultants observed that the increased number of claims was due to a lack of Complaints Officers within the telecom service providers. With the introduction of such officers at both Airtel and Cable \& Wireless (the only two mobile phone service providers in the country) the issue was rectified and the number of complaints to FTC dropped (ConsumerWeb 2016, 38).

Currently, FTC Consumer Affairs officers are registering similar surges in complaints on mobile data, and specifically: (i) poor quality of data service (internet connection speed inferior to what advertised), and (ii) data running out at suspiciously high speed. At the time of the interviews (May-June 2017) the 
departments of Consumer Affairs and Legal Affairs were in the process of collecting information from aggrieved consumers relating to data in order to collect sufficient evidence to lodge a formal complaint before the Board under section 40(1)(b) CPA - unsatisfactory quality of service provided.

\section{Interactions of Seychelles Consumer Law with International and Supranational Influences}

The influences that international guidelines and foreign legislation and policy have had on the shaping of Seychelles consumer law have been discussed throughout the paper. In addition to that, the NCP mentions "best practice and international cooperation" (FTC 2016a, 24) and sets international cooperation as one of the strategic goals for consumer law and policy in Seychelles, particularly “in the context of COMESA, SADC, ICPEN and UNCTAD's annual meeting of the IGE on Consumer Policy" (FTC 2016a, 24). Furthermore, the policy mentions the UNGCP as a framework for combatting fraudulent and deceptive commercial practices, and as a potential platform "for obtaining technical assistance" (FTC 2016a, 25). Nothing further is discussed and, thus, this part of the NCP appears to be underdeveloped. For instance, no guidance is offered on the proactive role Seychelles is supposed to play within these regional or international organizations, with emphasis limited to the passive role - such as the reference to potential technical assistance from UNGCP.

In discussions with FTC officers about interactions with supranational initiatives, two significant aspects emerge. First, there is little practical cooperation with African regional integration processes such as SADC and COMESA. For instance, it transpires that the FTC has signed an MOU with all SADC countries for the sharing of relevant information, however the MOU focuses on cartels and M\&A practices. In the words of FTC's Legal Advisor, "the impact of international interactions on consumer law in practice is limited". The shared feeling of FTC officers is that, within African regional initiatives, competition law is more developed and cared about than consumer law, and therefore interactions at that level tend to be much more focused on competition matters and to a lesser extent on consumer law. ${ }^{27}$ As a matter of fact, it should be noted that the "Agreement Establishing a Tripartite Free Trade Area among the Common Market for Eastern and Southern Africa, the East African Community and the Southern African Development Community" 28 makes no reference to consumer law or consumer protection.

The second element that emerges from the interviews is that the one supranational initiative deemed practically helpful by FTC legal and compliance officers is the African Consumer Protection Dialogue (ACPD). ACPD is described by Seychelles FTC delegates as a useful platform for consumer protection agencies

\footnotetext{
27 It is interesting to note that, when asked about interactions with SADC and COMESA in the field of consumer law, officers unanimously responded that the revised CPA Bill (currently in the process of being drafted) will "have to be in line with SADC and COMESA". However there seems to be a general lack of clarity as to what this entails practically. SADC has adopted a Declaration on Regional Cooperation in Competition and Consumer Policies (SADC 2009), but yet again, it appears that this instrument is perceived as more focused on competition than consumer policy.

${ }^{28}$ The agreement is available at https://www.tralac.org/resources/by-region/comesa-eac-sadctripartite-fta.html (last accessed 15 April 2018).
} 
to report every year on national policy and regulatory issues. While the format of ACPD is designed for the sharing of information and experience rather than actively developing policy or regulatory guidelines, for young and developing agencies such as the Seychelles FTC, exposure to such experience is invaluable. Specifically, the yearly input offered by representatives of the United States Federal Trade Commission to the ACPD is identified as a particularly helpful frame of reference - which is significant in terms of international influences, given that there are currently no bilateral or multilateral agreements involving Seychelles and the European Union containing rules or policy requirements regarding consumer protection.

\section{Conclusion}

Seychelles consumer law is an emerging legal field, developed in parallel to the recent arrival of consumerism to the country, and is now in the process of defining its own identity. Sources of inspiration for the legal framework are prevalently the UNGCP, EU Directives (especially on unfair contract terms), and the South African CPA, whereas FTC's policy initiatives tend to be modelled on other small island countries such as Barbados, Malta or Ireland (with the noticeable additions of Australia and New Zealand). It is no surprise that the natural "go tos" are Commonwealth countries and/or insular countries of relatively similar dimensions.

Overall, the legal framework on the books, while perfectible and in need of rationalization (starting with the consolidation of FTC provisions into the revised CPA), is modern and in line with international guidelines, and the FTC is an accessible, proactive and responsive agency. The challenges in action identified throughout the article can be summarised as follows. First, local standardization efforts are failing to address the matter of poor quality products entering the market, and there is insufficient reliance on international standards and practices. Secondly, consumers appear to be often reluctant to rely on the adjudicatory mechanism provided by the FTCA (especially as regards product safety and liability), to the extent that few complaints reach the quasi-judicial level of the Board, in favour of more informal mechanisms in which the FTC plays the role of a mediator-like figure. These mechanisms are arguably more adequate than formal procedures in a micro-jurisdiction like Seychelles. Yet this comes at the cost of depriving FTC officers and consumers of precious interpretative efforts by adjudicatory bodies (an obvious example being the key role of the CJEU in the development of European consumer law). Future reformatory and policy efforts are needed to make the adjudicatory scheme as accessible as possible in order to progressively build a corpus of interpretative decisions.

As is often the case in micro-jurisdictions, the issues discussed in this article are more a product of insufficient capacity than inadequacy of the legal framework. The FTC has identified sensible courses of action in its NCP to address structural limitations through interagency cooperation and reliance on international practices and experiences. It remains to be seen whether the NCP will receive the political endorsement that it requires in order to produce meaningful effects. 


\section{REFERENCES}

African Development Bank (2016). Republic of Seychelles: Country Strategy Paper 2016-2020, available at http://www.afdb.org/fileadmin/uploads/afdb/Documents/Project-andOperations/SEYCHELLES - CSP 2016-2020 - FINAL.pdf

Briguglio L. (1995). Small Island Developing States and their Economic Vulnerabilities. World Development 23, 1616-1632.

Consumer Affairs Victoria (2004). What do we mean by 'vulnerable' and 'disadvantaged' consumers? Consumer Affairs Victoria Discussion Paper.

ConsumerWeb (2016). Review Report - Seychelles' Fair Trading Commission Act, Fair Competition Act and Consumer Protection Act for Drafting of a Consolidated Law. Unpublished Report of the Seychelles' Fair Trading Commission.

Fair Trading Commission (2016a). National Consumer Policy, available at http://ftc.sc/index.php/consumer-protection/national-consumer-policy.

Fair Trading Commission (2016b). Fair Trading Commission, Seychelles - Annual Report 2016, available at http://ftc.sc/images/pdf/annualreport/Annual-Report2016.pdf

Fair Trading Commission (2015). Fair Trading Commission, Seychelles - Annual Report 2015, available at http://ftc.sc/images/pdf/annualreport/Annual-Report2015.pdf

Fair Trading Commission (2014). National Competition Policy, available at http://ftc.sc/index.php/fair-competition/national-competition-policy

Fair Trading Commission (2013). Fair Trading Commission, Seychelles - Annual Report 2013, available at http://ftc.sc/images/pdf/annualreport/Annual-Report2013.pdf

International Monetary Fund (2017). SEYCHELLES, Fourth and Fifth Reviews Under the Extended Arrangement and Request for Modification and Waiver of Applicability of Performance Criteria. IMF Country Report No. 17/51.

Kerr J. (2015). Finding the Law in Seychelles. GlobaLex, available at http://www.nyulawglobal.org/globalex/Seychelles.html

OECD (2010). Consumer Policy Toolkit. OECD Publishing.

Rizzi M. (2017). The Evolution of Consumer Product Safety Policy and Regulation in India. Journal of Consumer Policy 40, 389-412.

The Nation (2016). President Michel Resigns. The Nation (28 September 2016), available at http://www.nation.sc/article.html?id=251201 
Twomey M. (2013). The Republic of Seychelles: Introductory Note. In R. Wolfrum, R. Grote \& E. de Wet (Eds.), Constitutions of the World. Oxford: Oxford University Press.

Twomey M. (2017). Legal Métissage in a Micro-Jurisdiction: the Mixing of Common Law and Civil Law in Seychelles. Journal de Droit Comparé du Pacific, Collection 'Ex Professo' Volume VI.

United Nations (2017). UNDATA - A World of Information, Seychelles, available at http://data.un.org/en/iso/sc.html

United Nations, Office of the High Representative for the Least Developed Countries, Landlocked Developing Countries and Small Island Developing Countries (2018). About the Small Island Developing Countries, available at http://unohrlls.org/about-sids/

United Nations (2016). Guidelines for Consumer Protection.

UNCTAD/DITC/CPLP/MISC/2016/1 adopted by General Assembly Resolution 70/186 of 22 December 2015.

World Bank (2017). The World Bank in Seychelles - Overview, available at http://www.worldbank.org/en/country/seychelles/overview

World Bank (2016). Comparative data on Sub-Saharan Africa, available at https://data.worldbank.org/region/sub-saharan-africa

Wong E. (2017). Droit de Superficie: Coelho v Tailapathy. Unisey-SeyLII André Sauzier Legal Writing Competition, winning paper 2015/16, available at https://www.seylii.org/201516-andré-sauzier-legal-writing-competitionwinners 